\title{
The Application Of The Principle Of Notary Prudence In Knowing The Applicant By Notary
}

\author{
Gerin Prayoga ${ }^{1}$ and Jawade Hafidz ${ }^{2}$
}

Abstract. The purpose of this study was to: 1) To Know and analyze the application of the principle of notary prudence In Knowing the applicant. 2) To Detect and Analyze Effects Of Authentic And Notary Deed Not Applying the Precautionary Principle In Knowing the applicant. The data used in this study are primary data, secondary data and data that can support tertiary study, which was then analyzed by the method of description and interpretation.

Based on the results of data analysis concluded that: 1) The principle of recognizing User Services as referred to in paragraph (1) at least includes identification of User Services, User Verification Transaction Monitoring Services and User Services. Reporting to the Financial Transaction Analysis and Reporting Center (PPATK) is recommended if it is believed their suspicions of money laundering schemes will be carried out, the registration obligation remains to be done, the registration once for serving. Reporting through the application system GRIPS (Gatahering Report Information Processing System). 2) an authentic deed which turned out later proven to be pecucian money, then it becomes the responsibility of the applicant own. Notaries who do not register GRIPS, will apply sanctions in the form of the temporary closure of access to AHU account on line, and thus access to the system notary Legal Administration (SABH) will be automatically blocked.

Keywords: Notary; Precautionary Principle; Protection.

\section{Introduction}

Notary is a public official assigned by the general power to serve the needs of society will be a tool that provides certainty authentic evidence of civil law relations. Throughout authentic evidence is still required by the country's legal system the Notary office will still be needed existence in the community. ${ }^{3}$

Deed authentic made by the notary has the legal power very strong given the deed of authenticity is evidence that perfect, it is not uncommon for legislation requiring legal regulation of certain made in the certificate is authentic, such as the establishment of limited liability companies, cooperatives, warranty deed fiduciary, and so in addition the deed was made at the request of the parties. The positive law in Indonesia has set up a notary office in a special law, the government together with the House of Representatives set of Act No. 30 of 2004 concerning Notary, ${ }^{4}$ which has now been converted into Act No. 2 of 2014 On Notary.

The notarial deed must provide certainty that something of events and facts in the deed actually performed by a Notary or explained by the parties were facing at the time listed in the deed in accordance with the procedures specified in the deed. formally to prove the truth and certainty about the day, date, month, year, at (time) is facing, and the parties are facing, initials and signatures of the parties / pengadap,

\footnotetext{
${ }^{1}$ Students Master of Notary, Faculty of Law UNISSULA, Semarang, email: gerinprayoga57@gmail.com

2 Lecturer Master of Notary UNISSULA, Semarang

${ }^{3}$ Hartanti Sulihandari dan Nisya Rifiani (dalam buku Suparman Marzuki), 2017, Etika \& Kode Etik Profesi Hukum, FH UII Press, Yogyakarta, p. 63.

${ }^{4}$ Ibid., p. 5.
} 
witnesses and Notary Public, as well as proving what is seen, witnessed, heard Notary (the official deed / news show), and recorded information or statements of the parties / applicant (on the deed). ${ }^{5}$

Notaries in carrying out their duties must also recognize the users of services or applicant accordance with the provisions of Article 39 of Act No. 2 of 2014 concerning Notary. Whether the user of the service or good faith applicant example of the identity or authenticity of the information given. Apart from the authenticity of documents or applicant notary service users must also consider whether there are suspicious transactions carried out. Regarding the transaction suspicious transactions for the benefit or on behalf of the Service User. Process outlined in the Regulation of the Minister of Justice and Human Rights of the Republic of Indonesia Number 9 of 2017 About Principles Recognizing User Services For Notary. As stipulated in Government Regulation No. 43 Of 2015 on the Reporting Parties under the Prevention and Combating of Money Laundering shall apply the principles recognized notary service users.

Notaries must be working professionals who prioritize expertise which is based on the code of conduct and the provisions of the legislation in force (Article 3 Point 6 Law of the Republic of Indonesia Number 28 Of 1999 on State Implementation of the Clean and Free from Corruption, Collusion and Nepotism. In running tasks and positions Notary in addition to submissive and obedient to the Law Notary and the Code of Conduct would have to pay attention to basic principles, one of which is the principle of prudence. In terms of knowing the applicant attend the office. Notaries must really get to know the applicant, in order to avoid mistakes in identifying and run the duty in terms of a deed. the reading of the deed is important that the parties who signed and witnessed the birth certificate actually fully aware of the things that are agreed and stated as well as its legal consequences. ${ }^{6}$ So that would be the establishment of boundaries and a clear relationship of rights, responsibilities, obligations, and powers all the parties concerned (Article 3 of the Law On Public Service).

Regulation of the Minister of Justice and Human Rights of the Republic of Indonesia Number 9 Of 2017 About Principles Recognizing User Services For Article 2 requires that a Notary Public Notary to be careful in recognizing applicant and obliged to report suspicious transactions to the Financial Transaction Analysis and Reporting Center (PPATK). This regulation is to avoid the Notary as a means of money laundering activities.

Notary in performing an act of law must always act carefully so as notary before a deed, to examine all relevant facts into consideration by the applicable laws. Examining all the completeness and validity of the evidence or documents that were presented to the notary, as well as hear the applicant information or statements shall be conducted as the basis for the consideration set forth in the deed. If a notary less scrupulous in checking the facts is important, it means that the notary act cautiously. ${ }^{7}$

Problems arise when Notaries must know the applicant, either check the completeness and authenticity of the document shown, Notary also have to be careful whether the transaction will be made before a Notary is the result of money laundering or not. How does a notary to determine the transactions to be conducted applicant is the result of laundering money or not.

\footnotetext{
${ }^{5}$ Habib Adjie, 2010, Kebatalan Dan Pembatalan Akta Notaris, Refika Aditama, Surabaya, p.19, ${ }^{6}$ Freddy Haris \& Leny Helena, 2017, Notaris Indonesia, Lintas Cetak Publishig, Jakarta, p.77. ${ }^{7}$ M. Luthfan Hadi Darus, 2017, Hukum Notariat dan Tanggung Jawab Jabatan Notaris, cetakan pertama, UII Press, Yogyakarta p. 38-39.
} 
Volume 6 Issue 2, June 2019

Based on the background mentioned above, the authors are interested in doing further research to be manifested in a study entitled: "Application of the principle of notary prudence In the Run Task In Knowing the applicant By Notary". The formulation of the problem is as follows: How Applying the principle of notary prudence In the applicant Know ?, How Effects From Authentic And Notary Deed Not Applying the principle of prudence in the applicant Know?

\section{Research methods}

The method used in this research is the approach description and interpretation approach or interpretation, approach that is describing what their description of the condition or position of the law or non-law proposition. Interpretation approach or interpretation by Sudikno Mertokusumo cited by Ahmad Rifai is "one of the legal discovery method that provides an explanation of the text gambling laws, so that the scope of the rules in the law can be applied to certain legal events. ${ }^{8}$ Forms of interpretation used in this study is a grammatical interpretation. Grammatical interpretation is to interpret the words of the law according to the rules of language and grammar rules of law. This interpretation is appropriate efforts to try to understand a text of a rule of law.

\section{Results And Discussion}

\subsection{Application of the principle of notary prudence In Knowing the applicant.}

Application of the Precautionary Principle is obligatory within the Notary deed will include:

- Doing introduction to applicant based identity shown to the notary.

- Ask, then listen and watch on the desire or the will of the parties.

- Examine documentary evidence relating to the desire or the will of the parties.

- Providing advice and outlining the deed to satisfy the desire or the will of the parties.

- Fulfill all administrative techniques notary deed, such as reading, signing, provide copies and filing for minuta.

- Perform other obligations relating to the execution of duties and notary office. ${ }^{9}$

Notary profession exploited vulnerable to money laundering due to the confidentiality provisions granted under the Act such as the confidentiality of the relationship between the notary with clients as a tool in money laundering schemes.

Permenkumham No. 9 Of 2017 About Principles Recognizing User Services For Notary requires notaries carry out additional powers, namely the identification and identity verification of legality and transaction monitoring sources of funding the services used in connection with a deed other than those mandated by Act No. 2 of 2014 on the Amendment of Act No. 30 of 2004 concerning Notary of making authentic act and order. ${ }^{10}$

\footnotetext{
${ }^{8}$ Amiruddin dan H. Zainal Asikin, 2012, Pengantar Metode Peneletian Hukum, Cetakan ke-6, PT. Rajagrafindo Persada, Jakarta, p. 163.

${ }^{9}$ Habib Adjie, 2009, Meneropong Khazanah Notaris dan PPAT Indonesia (Kumpulan Notaris dan $P P A T)$, Citra Aditya Bakti, Bandung, p. 86.

${ }^{10}$ Results of interviews with Nur Chasanah Notary, dated 18 April 2019 in the Office of Notary and PPAT Jln. Kenanga Raya No. 320, Perum Wiku II, Demak.
} 
In the application of this rule, a notary is required to have policies and procedures to manage and mitigate the risk of money laundering and / or financing of terrorism identified in accordance with risk assessment and also conduct a risk assessment and classify the service user based on the level of risk of money laundering and criminal offenses funding terrorism is based on an analysis of the profile, businesses, countries and products. ${ }^{11}$

Article 2 of Regulation of the Minister of Law and Human Rights No. 9 of 2017 regulates the obligations of User Services Principles Recognizing that:

- Paragraph (1) shall apply the principles recognized Notary Service User.

- Paragraph (2) The principle of recognizing User Services as referred to in paragraph

(1) shall at least contain:

- User identification services;

- User verification services; and

- User Transaction Monitoring Services.

- Paragraph (3) Application of Recognizing User Services as referred to in paragraph (2) apply to Notaries in providing services such as preparing for and conducting transactions for the benefit of or on behalf of User Services, regarding:

- purchase and sale of property;

- management of money, securities, and / or other financial services products;

- management of current accounts, savings accounts, deposit accounts, and / or securities accounts;

- operation and management of the company; and / or;

- establishment, purchase, and sale of legal entities.

- Paragraph (4) The obligation to apply the principle of recognizing User Services as referred to in paragraph (1) and (2) performed at the time:

- a business relationship with the User Services

- there is a financial transaction with the rupiah currency and / or foreign currency whose value is at least equal to $100,000,000.00$ (one hundred million rupiah);

- There Suspicious Transactions related criminal offenses of money laundering and financing of terrorism a criminal offense; or

- Notary doubt the veracity of the information reported User Services.

Recognize the principle of service users which is mandatory for Notaries in addition to article 2 of Article 4 Notary is required:

- In applying the principle of recognizing the service users, the Notary shall:

- have policies and procedures to manage and mitigate the risk of money laundering and / or financing of terrorism identified in accordance with the risk assessment; and

- conduct a risk assessment and classify the service user based on the level of risk of money laundering and financing of terrorism a criminal offense.

- Service User Grouping based on risk level as referred to in paragraph (1) shall be based on an analysis of:

- profile;

- business;

- country; and

- product.

\footnotetext{
${ }^{11}$ https://irmadevita.com/2017/notaris-wajib-lapor-transaksi-mencurigakan-ke-ppatk/, Accessed on July $19,2019,19: 20 \mathrm{pm}$.
} 
Article 5 of Regulation of the Minister of Law and Human Rights No. 9 of 2017 About Principles Recognizing User Services For Notary regulating the prohibition against Notaries are:

- Notary paragraph banned open or maintain anonymous accounts or accounts with fictitious names are used.

- Subsection (2) Account referred to in paragraph (1) includes evidence of business relationship between the Notary Service User.

Application of the principle of notary prudence In Knowing the applicant Notaries in identifying and verifying the identity of legality and transaction monitoring service users source of funds used in connection with the deed. namely to: ${ }^{12}$

- "Mandatory understand the profile, goals and objectives of business relationships and transactions performed User Services"

- Examine documentary evidence relating to the desire or the will of the parties.

- Put sentence for Notary self protection, "according shown to me, Notary". That all letters / documents shown by the applicant to the Notary and contents specified in this deed, are letters / documents are correct, if one day prove to be incorrect is the responsibility of the applicant entirely and frees Notary of the result in civil and criminal law.

- Reporting to the Financial Transaction Analysis and Reporting Center (PPATK) is recommended if it is believed their suspicions of money laundering schemes will be carried out.

- There is no obligation to make Suspicious Transaction Reporting (STR) when there was nothing to report, but the registration obligation remains to be done, the registration once for serving.

- Reporting through the application system GRIPS (Gatahering Report Information Processing System).

Gathering Reports \& Information Processing System (GRIPS) is a system built by the Center for Transaction Reporting and Analysis (PPATK) to prevent and control of Money Laundering Act which may be done through a transaction using a notary to conceal or disguise the identity or origin wealth illegally acquired such property that appears to come from a legitimate source. ${ }^{13}$

Register once and for office, there is no obligation to do Suspicious Transaction Reporting (STR) when there was nothing to report, but the registration obligation remains to be done.

Stages registration / registration GRIPS INTRAC carried out through two (2) phases, namely: ${ }^{14}$

- Register online through the page: https://grips2.ppatk.go.id/faces/registrasi.xhtml; Video tutorials can be found at: http://www.ppatk.go.id/video/lists/1.html

- The obligation to submit the results of physical documents to the INTRAC register online no later than seven (7) working days after registration,

\footnotetext{
${ }^{12}$ Results of interviews with Nur Chasanah Notary, dated 18 April 2019 in the Office of Notary and PPAT Jln. Kenanga Raya No. 320, Perum Wiku II, Demak.

${ }^{13}$ Results of interviews with Andrian Notary, dated 22 April 2019 at the office of the Notary and PPAT Highway of Mranggen No. 83.A, Demak.

14 http://portal.ahu.go.id/id/detail/40-pengumuman-penting/2186-pengumuman together, Accessed on July 19, 2019, 20:15 pm.
} 


\subsection{Effects Of Authentic And Notary Deed Not Applying the Precautionary Principle In Knowing the Parties.}

Position of the authentic act which turned out later proven to be pecucian applicant money is a responsibility for the Material Aspects (materiele bewijskracht), every person who came later statement contained or contained in the certificate must be considered to have correctly said. If it turns out the applicant statements or information are to be incorrect, then it becomes the responsibility of the applicant own. ${ }^{15}$

The legal consequences of the unlawful act committed by a Notary in making authentic deed is basically the occurrence of a case in which public officials had been looking for a profit and abusing the authority that has been stipulated in Law Amendment UUJN and a client or applicant others feel aggrieved over terbuatnya deed which contains elements of a tort committed by a Notary, resulting in an authentic deed of Notary may be canceled or can be canceled. ${ }^{16}$

As a public official makes an authentic deed, the notary is responsible for the deed he made later when a dispute relating to the deed. The responsibility of notaries in evidence in the trial of criminal cases may occur when the deed into problems that require the notary to provide information and testimony relating to the formal and substantive aspects of the deed. ${ }^{17}$

Last result from notaries who did not apply the precautionary principle in the applicant familiar with do not support regulation and Human Rights Act No. 9 of 2017 About Principles Recognizing User Services For Notary. Ministry of Law and Human Rights provides in applying administrative sanctions for the notaries who do not meet its obligations regarding the registration Grips is a form of support from the Ministry of Justice and Human Rights as partners in the implementation of this application INTRAC. This is confirmed by the Directorate General of AHU, that as of May 7, 2019 when they Notary yet to register GRIPS will be subject to sanctions in the form of a temporary closure of access to the account AHU on line, and thus access the notary system Legal Administration (SABH) will be automatically blocked. ${ }^{18}$

\section{Closing}

\subsection{Conclusion}

Based on the research results can be concluded as follows:

- Notary profession exploited vulnerable to money laundering due to the confidentiality provisions granted under the Act such as the confidentiality of the relationship between the notary with clients as a tool in money laundering schemes. Permenkumham No. 9 Of 2017 On the Application of Know User Services For Notary requires notaries carry out additional powers, namely the identification and identity verification of legality and transaction monitoring sources of funding the services used in connection with a deed other than those mandated by Act No. 2 of 2014 on the Amendment of Act No. 30 of 2004 concerning Notary of making authentic act

\footnotetext{
${ }^{15}$ Results of interviews with Nur Chasanah Notary, dated 18 April 2019 in the Office of Notary and PPAT Jln. Kenanga Raya No. 320, Perum Wiku II, Demak.

${ }^{16}$ Results of interviews with Andrian Notary, dated 22 April 2019 at the office of the Notary and PPAT Highway of Mranggen No. 83.A, Demak.

${ }^{17}$ Ibid.

${ }^{18}$ Notary Results of interviews with Sandy Rahardjo, dated 23 April 2019 in the Office of Notary and PPAT Road Bandungrejo No. 46, Mranggen, Demak.
} 
and order. ${ }^{19}$ Registration Gathering Reports \& Information Processing System (GRIPS) once for serving

- Position of the authentic act which turned out later proven to be pecucian applicant money is a responsibility for the Material Aspects (materiele bewijskracht), every person who came later statement contained or contained in the certificate must be considered to have correctly said. If it turns out the applicant statements or information are to be incorrect, then it becomes the responsibility of the applicant own. ${ }^{20}$ That as of May 7, 2019 when they last notaries who have not done GRIPS registration will be subject to sanctions in the form of a temporary closure of access to AHU account on line, and thus access to the system notary Legal Administration $(\mathrm{SABH})$ will be automatically blocked. ${ }^{21}$

\subsection{Suggestion}

- Notary identifying, monitoring, and providing reports on transactions conducted by the Service User. namely with his best records. Self-protection for the Notary very influential, given the duty jabatanya need for protection for himself. Before the deed presented with the statement, the parties guarantee the authenticity of which was shown to me, Notary.

- Registration Gathering Reports \& Information Processing System (GRIPS) once for office, there is no obligation to do Suspicious Transaction Reporting (STR) when there was nothing to report, but the registration obligation remains to be done.

\section{Bibliography}

[1] Habib Adjie, 2007, Hukum Notaris Indonesia (Tafsir Tematik Terhadap UndangUndang Nomor 30 Tahun 2004 Tentang Jabatan Notaris), (Selanjutnya Disebut Habib Adjie I), Surabaya : PT. Refika Aditama.

[2] Habib Adjie, 2010 Kebatalan Dan Pembatalan Akta Notaris, Surabaya : Refika Aditama.

[3] Hartanti Sulihandari Dan Nisya Rifiani, 2017, (Dalam Buku Suparman Marzuki), Etika \& Kode Etik Profesi Hukum, Yogyakarta : FH UII Press.

[4] Freddy Haris \& Leny Helena, 2017, Notaris Indonesia, Jakarta : Lintas Cetak Publishig.

[5] M. Luthfan Hadi Darus, 2017 Hukum Notariat dan Tanggung Jawab Jabatan Notaris, cetakan pertama, Yogyakarta : UII Press.

[6] Amiruddin Dan H. Zainal Asikin, 2012, Pengantar Metode Peneletian Hukum, Cetakan Ke-6, Jakarta : PT. Rajagrafindo Persada.

[7] Habib Adjie, 2009, Meneropong Khazanah Notaris Dan PPAT Indonesia (Kumpulan Notaris Dan PPAT), Bandung : Citra Aditya Bakti.

[8] Act No. 2 of 2014 on the Amendment of Act No. 30 of 2004 concerning Notary.

[9] Act No. 28 of 1999 on State Implementation of the Clean and Free from Corruption, Collusion and Nepotism.

\footnotetext{
${ }^{19}$ Results of interviews with Nur Chasanah Notary, dated 18 April 2019 in the Office of Notary and PPAT Jln. Kenanga Raya No. 320, Perum Wiku II, Demak.

${ }^{20}$ Results of interviews with Nur Chasanah Notary, dated 18 April 2019 in the Office of Notary and PPAT Jln. Kenanga Raya No. 320, Perum Wiku II, Demak.

${ }^{21}$ Notary Results of interviews with Sandy Rahardjo, dated 23 April 2019 in the Office of Notary and PPAT Road Bandungrejo No. 46, Mranggen, Demak.
} 
[10] Regulation of the Minister of Law and Human Rights No. 9 Of 2017 About Principles Recognizing User Services For Notary.

[11] https://irmadevita.com/2017/notaris-wajib-lapor-transaksi-mencurigakan-keppatk/, Accessed on July 19, 2019, 19:20 pm.

[12] http://portal.ahu.go.id/id/detail/40-pengumuman-penting/2186-pengumuman together, Accessed on July 19, 2019, 20:15 pm. 